Sains Malaysiana 51(1)(2022): 297-306

http://doi.org/10.17576/jsm-2022-5101-24

\title{
Evaluation of the Male and Female Fertility and Teratogenic Effects of Lignosus rhinocerotis (Cooke) Ryvarden in Rats
}

(Penilaian Fertiliti Tikus Jantan dan Betina dan Kesan Teratogenik Lignosus rhinocerotis (Cooke) Ryvarden)

\author{
Zati Bayani Hamzah, Bushra Solehah Mohd Rosdan, Nurul Asma Abdullah \& Wan Ezumi Mohd \\ FUAD*
}

\section{ABSTRACT}

Lignosus rhinocerotis (Cooke) Ryvarden (LR) or tiger milk mushroom has traditionally been used in Malaysia due to its abundant medicinal properties. The potential effects of $L R$ on the male and female fertility and teratogenicity were investigated on rats. Male Sprague Dawley (10 rats/group) were orally administered with 0, 250, 500 and $1000 \mathrm{mg} / \mathrm{kg} /$ day of LR extract for 30 consecutive days. Female (5 rats/group) received the same treatment beginning the dioestrus of pre-mating, through mating periods and continuously up to day 20 of pregnancy while the rest of the females (5 rats/group) were left untreated. Evaluation on general health, behaviour, body weight and organ weights; reproductive and internal organs were carried out. Male fertility parameters such as the reproductive performance and hormones as well as sperm analysis were examined. Maternal gross assessment at autopsy and detailed foetal examination were conducted to determine the teratogenicity. The findings obtained on the male animals showed that no significant deleterious effects on the general health, body weight, reproductive and visceral organs weight, reproductive performance, hormones and sperm analysis of up to $1000 \mathrm{mg} / \mathrm{kg} /$ day daily doses of LR. Foetal parameters and gross examination of pregnant dams at autopsy showed that the extract did not affect the fertility of the rats and teratogenicity of the litters. Our findings showed that no treatment-related toxicity on the fertility of male and female rats in all groups following $L R$ treatment. The herbal extract also did not result in teratogenic effects on the offspring of the treated dams.

Keywords: Fertility: Lignosus rhinocerotis; reproductive performance; teratogenicity

ABSTRAK

Lignosus rhinocerotis (Cooke) Ryvarden (LR) atau cendawan susu rimau telah digunakan secara tradisi di Malaysia kerana potensinya yang banyak dalam bidang perubatan. Kesan LR terhadap fertiliti tikus jantan dan betina serta kesan teratogenisiti dikaji ke atas tikus. Sprague Dawley jantan (10 tikus/kumpulan) diberikan 0, 250, 500 dan $1000 \mathrm{mg} / \mathrm{kg} / \mathrm{hari}$ dos ekstrak LR secara oral selama 30 hari berturutan. Tikus betina (5 tikus/kumpulan) menerima rawatan yang sama bermula dari tempoh diestrus pra-mengawan, melalui tempoh mengawan dan berterusan sehingga hari ke-20 kehamilan manakala tikus betina yang selebihnya (5 tikus/kumpulan) tidak dirawat. Penilaian terhadap kesihatan umum, tingkah laku, berat badan dan berat organ; organ reproduktif dan organ dalaman telah dijalankan. Parameter fertiliti bagi tikus jantan seperti prestasi dan hormon reproduktif serta analisis sperma telah diperiksa. Penilaian kasar semasa autopsi ke atas tikus betina dan pemeriksaan teliti ke atas fetus dijalankan untuk menentukan kesan teratogenisiti. Penemuan yang diperoleh pada tikus jantan menunjukkan tiada kesan buruk terhadap kesihatan umum, berat badan, berat organ reproduktif, berat organ dalaman, prestasi reproduktif, analisis hormon dan sperma sehingga dos harian LR $1000 \mathrm{mg} / \mathrm{kg}$ / hari. Parameter bagi fetus dan pemeriksaan kasar terhadap tikus hamil semasa autopsi mendedahkan bahawa ekstrak LR tidak menjejaskan fertiliti tikus betina dan teratogenisiti anak tikus. Penemuan kami menunjukkan bahawa rawatan ekstrak LR tidak menyebabkan kesan toksik terhadap fertiliti tikus jantan dan betina dalam semua kumpulan. Ekstrak herba ini juga tidak menyebabkan kesan teratogenik kepada anak tikus dari ibunya yang dirawat.

Kata kunci: Fertiliti; Lignosus rhinocerotis; prestasi reproduktif; teratogenisiti

\section{INTRODUCTION}

Lignosus rhinocerotis (Cooke) Ryvarden (LR) or locally known as tiger milk mushroom is one of the valuable medicinal mushrooms with abundant therapeutic properties. It has long been recognized among the indigenous communities of Peninsular Malaysia for the 
treatment of numerous diseases including fever, cough, asthma, cancer, and as a general tonic for the promotion of health (Lee et al. 2011).

Toxicity study of new compounds is very crucial in the new drug development to deal with the potential toxins and poison contents that may affect the treatment. Several numbers of scientific data regarding the therapeutic properties of this fungus are currently available. Previously, several studies on sub-acute and chronic toxicity had been performed using the LR extract. According to Lee et al. (2011), oral administration of different types of sclerotial powder did not induce general toxicity in rats even at $1000 \mathrm{mg} / \mathrm{kg}$ daily for 28 days study period. Meanwhile, a preliminary study experiment by Lee et al. (2013) suggests that sclerotial powder of LR did not exhibit any peculiar effect on the female fertility or teratogenicity of the offspring. However, the fertility effects on male rat was not executed and only two groups (control and treatment group) of female rats (5 rats/group) with only one dose of extract used $(100 \mathrm{mg} / \mathrm{kg})$ were screened for fertility and teratogenicity.

The aqueous and methanol LR extracts tested on non-cancerous cell lines showed no toxicity was detected (Lau et al. 2013; Lee et al. 2012; Suziana Zaila et al. 2013). The hot and cold aqueous and ethanol of LR extracts had been reported to cause no toxic effect when treated on RAW264.7 macrophages cells and BV2 microglial cells (Baskaran 2015; Nallathamby et al. 2016). BV2 microglial cells also showed to be non-toxic when tested with the fractions of ethanol, hexane and ethyl acetate from the sclerotium of LR (Nallathamby et al. 2016).

The aforementioned findings could be the evidence of a huge potential of LR to be developed as a therapeutic agent or other health-related products. Despite its medicinal potential, the scientific input on its safety is highly required to help make justification on the safety level of LR. Therefore, the present study was conducted to complement the toxicity data particularly on male and female fertility including teratogenicity of the offspring in order to ensure the broader safety profiles of this herb.

\section{Materials AND Methods}

\section{HOT WATER EXTRACTION OF LR}

Sclerotial powder of LR cultivar TM02 was commercially obtained from the Ligno Biotech Sdn Bhd, Selangor, Malaysia. The hot water extraction was carried out using soxhlet apparatus. The soxhlet was run for $24 \mathrm{~h}$ with distilled water as solvent. The extracted sample was freeze-dried and kept in $4{ }^{\circ} \mathrm{C}$ prior to use.

\section{ANIMALS AND EXPERIMENTAL DESIGN}

This experiment was approved by the USM Institutional Animal Care and Use Committee (IACUC) with the reference number: (USM/Animal Ethics Approval/2013/ (90)(502)). The present methods for male and female toxicity assessments were adapted and modified from the OECD guidelines No. 422 (OECD 2016). Eighty healthy Sprague Dawley (SD) rats at the age of 9-10 weeks old comprising of the equal numbers between male and female were utilized in this study. All rats within the acceptable range of weight, 200-210 g for males and 180-190 $\mathrm{g}$ for females were supplied and maintained at the Animal Research and Service Centre (ARASC), USM Health Campus, Kubang Kerian, Kelantan, Malaysia. They were maintained at $22 \pm 2{ }^{\circ} \mathrm{C}$ (relative humidity of $50-60 \%$ ) with a $12 \mathrm{~h}$ light/dark cycle (lights on from 0700 to $1900 \mathrm{~h}$ ). The animals had free access to commercially obtained pelleted rat chow and distilled water ad libitum.

\section{MALE FERTILITY STUDY}

LR extract at doses of 0 (control), 250, 500 and 1000 $\mathrm{mg} / \mathrm{kg} /$ day were orally administered to four groups of male SD rats (10 rats/group) consecutively for 30 days beginning 14 days prior to mating, during the mating and post-mating periods. Following LR treatment, each male was separated into a single cage with an untreated fertile (proestrus) female for mating. Indices of mating and fertility were then calculated based on this observation. The males were also observed daily for mortality, moribundity, general appearance and behaviour throughout the study. They were closely examined for any signs of toxicity including physical changes in fur, skin, eyes, mucous membrane, posture and assessment of irregular motor activity and behaviour as well as the occurrence of abnormal excretion and secretions. Additionally, daily body weight and weekly food consumption were recorded for all animals.

At the end of experimental period, the males were fasted overnight prior to necropsy which was 1 day after the 30th administration. On D31, the male rats were anaesthetised with sodium pentobarbital prior to laparotomy. Blood were collected from the abdominal aorta for serum hormonal (testosterone, FSH, LH) assays. Internal reproductive organ; testes, epididymis, seminal vesicle and prostate glands were removed, 
blotted dry, weighed, and examined macroscopically. Cauda epididymis was further processed for sperm count evaluation referring to the method made by Hilmi et al. (2013).

\section{FEMALE FERTILITY AND TERATOGENICITY}

The females (10 rats/group) were also allocated into four treatment groups (similar dosage groups as of males). In each group, five females were treated with LR extract while another five females were left untreated as a concurrent control. These untreated control females were important to allow fair observation on the effects of reproductive performance showed by the treated males when they were mating. LR administrations to the treated females were started on the first day of dioestrus during the two weeks of pre-mating and continuously throughout the mating and gestation periods of up to day 20 of pregnancy. The oestrous cycles of all females were determined by taking daily vaginal smears from the start of the study until pregnancy has confirmed. Each pregnancy was effectively induced by separately caging each female with a male of similar dose group overnight in 1:1 mating ratio. A sperm positive vaginal smear in the following morning confirmed that mating has taken place, and this was considered as day zero (D0) of pregnancy. Daily observations on the physical appearance and behaviour of the female rats were conducted similarly to the males at the pre-, mid- and post-treatment periods. On D21 of pregnancy, all females were laparotomised to allow examination of uterine contents and foetuses. Upon completion of the external organ examination, the abdominal viscera were exposed by making an incision through the abdominal muscles and peritoneum up to the sternum. The abdominal cavity was opened and gross internal examinations of maternal organs such as uterus, ovaries, vagina, adrenal glands, liver, spleen, kidney and gastrointestinal tract were performed and subsequently removed from the body for further evaluation. These organs were cleared of adhering tissue, weighed and examined macroscopically.

The isolated uteri were incised, showing the position of implantations and counted for early resorption (no embryonic tissue visible at termination) or late resorption (placental and embryonic tissue visible at termination) and dead or live foetuses. Uteri of non-pregnant dams were stained with $0.5 \%$ ammonium sulphide solution for ten minutes to confirm the absence of implantation sites. Dark residues provided evidence that pregnancy has occurred, and these were recorded as early resorptions.
The umbilical cord of each foetus was cut and foetuses were carefully removed, blotted dry, counted, weighed and checked for their sexes. Head, eyes, palate, nares, limbs, neck, spine, chest, abdomen, orifices, tails and genitals of the foetuses were carefully examined under dissecting stereomicroscope to locate for any morphological abnormalities.

\section{STATISTICAL ANALYSIS}

All numerical data from this study were analysed using SPSS IBM version 22. The data of mean body weight of males and females were analysed using General Linear Model (GLM) Repeated Measure. Most data for toxicity and fertility of both sexes as well as teratogenicity effects (parametric data) were analysed using one-way analysis of variance (ANOVA) and expressed as mean \pm standard error of mean. Additionally, Kruskal Wallis test was used for the percentage of pre-implantation loss (non-parametric data) and expressed as median (IQR). Chi-square test was also applied to evaluate the differences of foetal gender in all groups. The 0.05 level of probability was used as the criterion for significance.

\section{RESULTS AND DISCUSSION}

This present study utilised hot aqueous extract of LR to further investigate its potential toxicity towards the reproductive capacity of both male and female Sprague Dawley rats. This study showed that no significant adverse effects were observed on the tested rats when treated with four different doses; 0, 250, 500, or 1000 $\mathrm{mg} / \mathrm{kg} /$ day of LR extract. All animals survived in healthy conditions throughout the treatment period and none have shown any visible sign of toxicity. Since both male and female rats showed a similar normal weight gain throughout the study period, it is suggested the LR extract is non-toxic to the rats (Figure 1). Body weight changes have been commonly used to indicate the adverse effects due to the drugs and chemicals exposure (Hilaly et al. 2004; Mukinda \& Eagles 2010; Teo et al. 2002).

Male fertility study was carried out by experimenting with the mating activities and fertility indices as shown in Table 1. The result of this study implies that oral administration of LR extract did not interfere with the male fertility at all doses tested. Figure 2(a) shows the mean of sperm count (million/cauda) between the treated and control male rats. Statistical analysis showed that there were no significant changes in the sperm count among all groups of animals. Increase production of 
a)

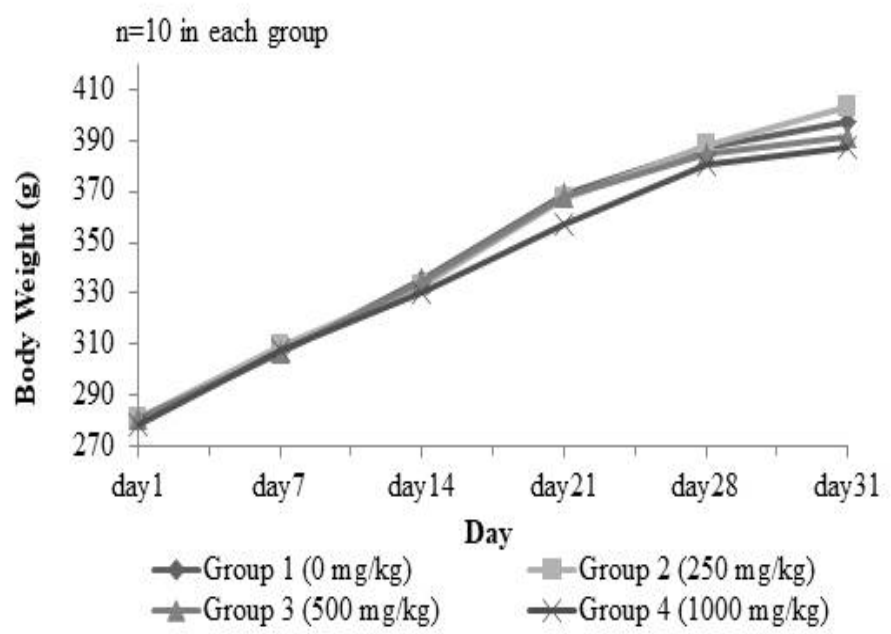

b)

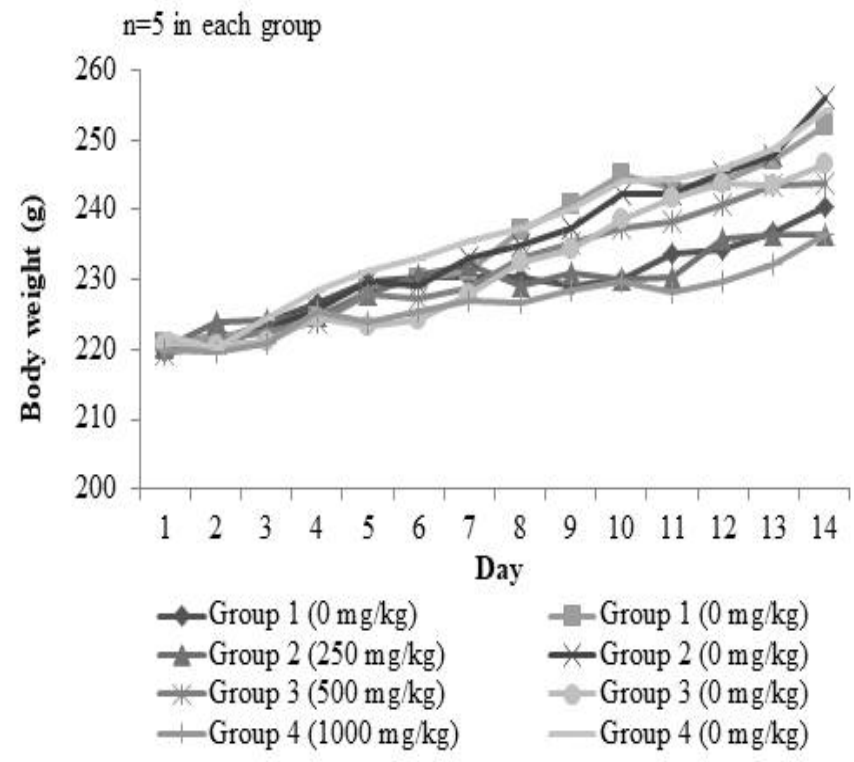

FIGURE 1. a) Body weight of male rats from day 1 to day 31 between LR-treated and vehicle control groups, (b) Body weight of female rats during 14 days of pre-mating period between LR-treated and vehicle control groups. There were no significant differences $(p>0.05)$ in the body weights of both male and female animals throughout the experiment

sperm was observed in the highest dose group (LR 1000 $\mathrm{mg} / \mathrm{kg} /$ day), suggesting that the extract might have a potential in boosting male fertility. The production of the male reproductive hormones; testosterone, FSH and LH also exhibited no differences in all tested groups. However, the increment of serum testosterone level (Figure 2(b)) was observed in the highest group (LR 1000 $\mathrm{mg} / \mathrm{kg} /$ day), which was further supported by the increase of sperm count even though these two parameters were statistically insignificant. Gonadotrophin-releasing hormone $(\mathrm{GnRH})$ secreted by the hypothalamus acts on the pituitary gland to release the gonadotrophin; FSH and LH (Marques et al. 2018). Leydig cells found in the seminiferous tubules of the testes produce testosterone when it is stimulated by LH. The binding of FSH to the receptor on the Sertoli cell helps in testicular growth 
and enhances secretion of androgen-binding protein that binds specifically to the testosterone and promotes spermatogenesis (Oduwole et al. 2018). Insufficient secretion of FSH and LH contributes to infertility due to the interruption in testicular performance (Babu et al. 2004).

TABLE 1. Effects of LR on the reproductive performance of male rats

\begin{tabular}{|c|c|c|c|c|c|}
\hline \multirow{2}{*}{ Parameters } & Group 1 & Group 2 & Group 3 & Group 4 & \multirow{2}{*}{$p$-value } \\
\hline & $0 \mathrm{mg} / \mathrm{kg}$ & $250 \mathrm{mg} / \mathrm{kg}$ & $500 \mathrm{mg} / \mathrm{kg}$ & $1000 \mathrm{mg} / \mathrm{kg}$ & \\
\hline Male survived (\%) & 100 & 100 & 100 & 100 & - \\
\hline Mating index (\%) & $100 \pm 0$ & $100 \pm 0$ & $100 \pm 0$ & $100 \pm 0$ & $\mathrm{n} / \mathrm{s}$ \\
\hline Fertility index $(\%)$ & $100 \pm 0$ & $100 \pm 0$ & $100 \pm 0$ & $100 \pm 0$ & $\mathrm{n} / \mathrm{s}$ \\
\hline
\end{tabular}

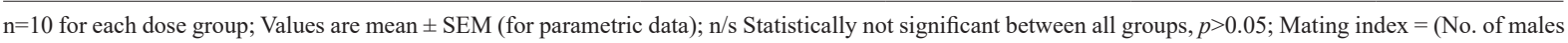
mated/No. of males cohabited $) \times 100 ;$ Fertility index $=($ No. of males impregnated females $/$ No. of males mated $) \times 100$

a)

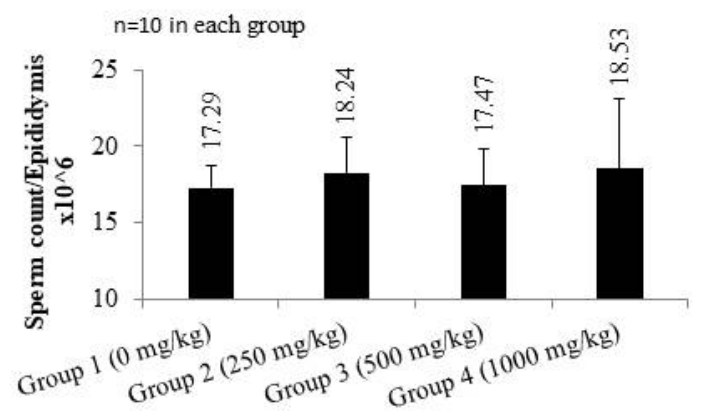

c)

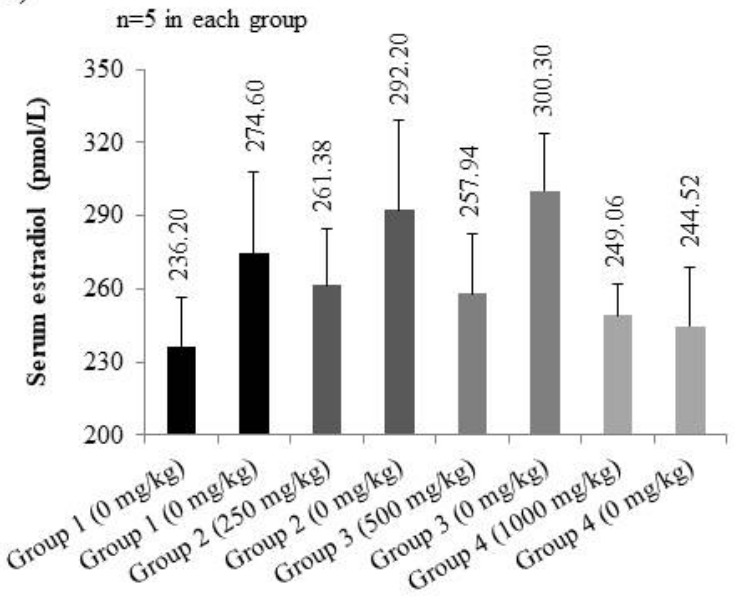

b)

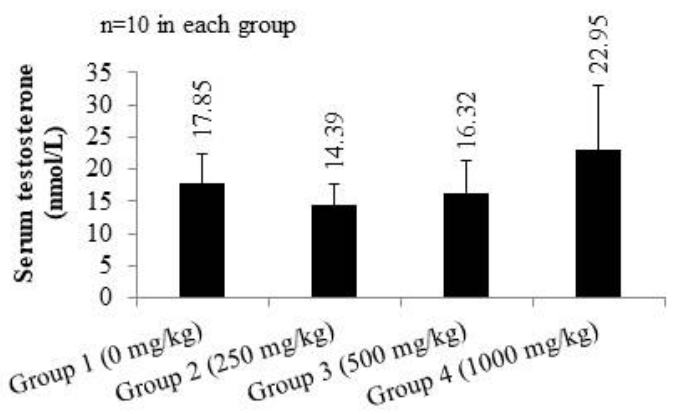

d)

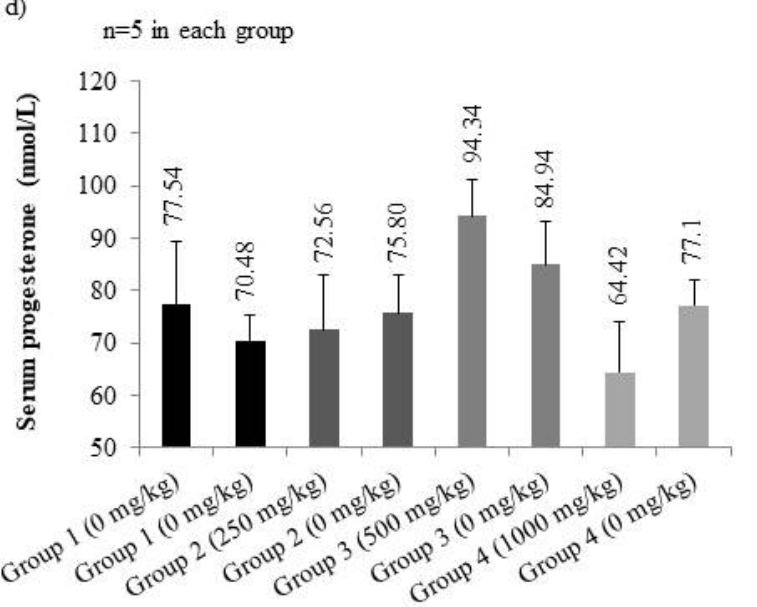

FIGURE 2. Fertility parameter and reproductive hormones of rats treated with LR extract (a)

Mean of sperm count (million/cauda) in male rats, (b) Mean of serum testosterone (nmol/L) in male rats, (c) Mean of serum oestradiol ( $\mathrm{pmol} / \mathrm{L}$ ) in female rats, (d) Mean of serum progesterone $(\mathrm{nmol} / \mathrm{L})$ in female rats. There were no significant differences $(p>0.05)$ in the fertility parameter and reproductive hormones of all rats treated with LR extract 
In female rats, the findings obtained showed that no significant differences were detected in all fertility parameters tested (Table 2). Successful mating was regarded when all sperm positive females were pregnant. Similarly, oestradiol, progesterone, FSH and LH were not significant in both treatment and control groups as shown in Figure 2(c) and 2(d) and Table 2. The pituitary gland secretes FSH for the development and growth of the ovarian follicle whereas LH is responsible to control oestrogen and progesterone hormones during the oestrous cycle (Coss et al. 2003; Thackray 2014). High levels of oestradiol and progesterone exhibited in this present study were to support pregnancy due to their function to thicken the endometrial lining, avoid uterine contraction and prevent the egg from further maturing (Young 2013).

The changes in visceral organ weight have been widely accepted as a sensitive indicator in the evaluation of test chemical-associated toxicity (Michael et al. 2007;
Sellers et al. 2007). The sensitive nature of organ weights towards drug toxicity is vital to be identified because it is frequently anteceding the morphological changes (Piao et al. 2013). Table 3 demonstrates the mean of absolute and relative weights of male reproductive organs; testis, epididymis, seminal vesicle and prostate gland from the treated and control groups. Meanwhile, Table 4 shows the mean of absolute and relative weights of female reproductive organs; ovary, fallopian tube, and cervix from all-female groups. Overall, the absolute and relative weight of male and female reproductive organs were not affected by LR treatment and showed a similar weight as in the control group. Similarly, the weight of other internal organs for both males and females such as liver, kidney and adrenal gland were not statistically significant when compared to the control group (data not shown). The results conclude that the aqueous extract of LR did not exert perturbed effects on the reproductive systems of rats.

TABLE 2. Female fertility parameters and reproductive hormones of LR-treated and untreated groups

\begin{tabular}{|c|c|c|c|c|c|c|c|c|c|}
\hline \multirow{2}{*}{ Parameters } & \multicolumn{2}{|c|}{ Group 1} & \multicolumn{2}{|c|}{ Group 2} & \multicolumn{2}{|c|}{ Group 3} & \multicolumn{2}{|c|}{ Group 4} & \multirow{2}{*}{$p$-value } \\
\hline & \multicolumn{2}{|c|}{ Control (0 mg/kg) } & \multirow[t]{2}{*}{$250 \mathrm{mg} / \mathrm{kg}$} & \multirow[t]{2}{*}{$0 \mathrm{mg} / \mathrm{kg}$} & \multirow[t]{2}{*}{$500 \mathrm{mg} / \mathrm{kg}$} & \multirow[t]{2}{*}{$0 \mathrm{mg} / \mathrm{kg}$} & \multirow[t]{2}{*}{$1000 \mathrm{mg} / \mathrm{kg}$} & \multirow[t]{2}{*}{$0 \mathrm{mg} / \mathrm{kg}$} & \\
\hline & & & & & & & & & \\
\hline $\begin{array}{l}\text { No. of pregnant } \\
\text { rats survived }\end{array}$ & $5 / 5$ & $5 / 5$ & $5 / 5$ & $5 / 5$ & $5 / 5$ & $5 / 5$ & $5 / 5$ & $5 / 5$ & $\mathrm{n} / \mathrm{s}$ \\
\hline Mating index (\%) & $100 \pm 0$ & $100 \pm 0$ & $100 \pm 0$ & $100 \pm 0$ & $100 \pm 0$ & $100 \pm 0$ & $100 \pm 0$ & $100 \pm 0$ & $\mathrm{n} / \mathrm{s}$ \\
\hline $\begin{array}{l}\text { Pregnancy index } \\
(\%)\end{array}$ & $100 \pm 0$ & $100 \pm 0$ & $100 \pm 0$ & $100 \pm 0$ & $100 \pm 0$ & $100 \pm 0$ & $100 \pm 0$ & $100 \pm 0$ & $\mathrm{n} / \mathrm{s}$ \\
\hline $\begin{array}{l}\text { Days for successful } \\
\text { mating }\end{array}$ & $3.80 \pm 0.38$ & $2.80 \pm 0.80$ & $3.40 \pm 1.50$ & $3.40 \pm 1.50$ & $4.00 \pm 0.95$ & $5.60 \pm 0.93$ & $3.40 \pm 0.93$ & $3.20 \pm 1.02$ & $\mathrm{n} / \mathrm{s}$ \\
\hline \multicolumn{10}{|c|}{ Reproductive hormones } \\
\hline $\begin{array}{l}\text { Luteinizing } \\
\text { hormone (LH) }\end{array}$ & 0 & 0 & 0 & 0 & 0 & 0 & $0.02 \pm 0.009$ & $0.02 \pm 0.009$ & $\mathrm{n} / \mathrm{s}$ \\
\hline $\begin{array}{l}\text { Follicle stimulating } \\
\text { hormone (FSH) }\end{array}$ & $0.03 \pm 0.008$ & $0.05 \pm 0.009$ & $0.05 \pm 0.009$ & $0.05 \pm 0.009$ & $0.05 \pm 0.009$ & $0.05 \pm 0.009$ & $0.05 \pm 0.009$ & $0.05 \pm 0.009$ & $\mathrm{n} / \mathrm{s}$ \\
\hline
\end{tabular}


TABLE 3. Absolute and relative weights of the male reproductive organs from the treated and control groups

\begin{tabular}{|c|c|c|c|c|c|}
\hline Parameters & Group 1 & Group 2 & Group 3 & Group 4 & $p$-value \\
\hline & $0 \mathrm{mg} / \mathrm{kg}$ & & & & \\
\hline \multicolumn{6}{|l|}{ Right testis } \\
\hline Absolute weight (g) & $1.68 \pm 0.08$ & $1.69 \pm 0.06$ & $1.57 \pm 0.07$ & $1.68 \pm 0.05$ & $\mathrm{n} / \mathrm{s}$ \\
\hline Relative weight (\%) & $0.42 \pm 0.02$ & $0.42 \pm 0.01$ & $0.40 \pm 0.02$ & $0.43 \pm 0.02$ & $\mathrm{n} / \mathrm{s}$ \\
\hline \multicolumn{6}{|l|}{ Left testis } \\
\hline Absolute weight (g) & $1.68 \pm 0.09$ & $1.68 \pm 0.06$ & $1.61 \pm 0.06$ & $1.68 \pm 0.05$ & $\mathrm{n} / \mathrm{s}$ \\
\hline Relative weight (\%) & $0.42 \pm 0.02$ & $0.41 \pm 0.01$ & $0.42 \pm 0.02$ & $0.43 \pm 0.01$ & $\mathrm{n} / \mathrm{s}$ \\
\hline \multicolumn{6}{|l|}{ Right epididymis } \\
\hline Absolute weight (g) & $0.59 \pm 0.02$ & $0.62 \pm 0.02$ & $0.62 \pm 0.03$ & $0.62 \pm 0.03$ & $\mathrm{n} / \mathrm{s}$ \\
\hline Relative weight (\%) & $0.15 \pm 0.006$ & $0.15 \pm 0.006$ & $0.16 \pm 0.006$ & $0.16 \pm 0.006$ & $\mathrm{n} / \mathrm{s}$ \\
\hline \multicolumn{6}{|l|}{ Left epididymis } \\
\hline Absolute weight (g) & $0.61 \pm 0.03$ & $0.63 \pm 0.03$ & $0.62 \pm 0.03$ & $0.62 \pm 0.03$ & $\mathrm{n} / \mathrm{s}$ \\
\hline Relative weight (\%) & $0.15 \pm 0.006$ & $0.16 \pm 0.006$ & $0.16 \pm 0.006$ & $0.17 \pm 0.006$ & $\mathrm{n} / \mathrm{s}$ \\
\hline \multicolumn{6}{|l|}{ Seminal vesicle } \\
\hline Absolute weight (g) & $1.14 \pm 0.08$ & $1.20 \pm 0.10$ & $1.31 \pm 0.15$ & $1.15 \pm 0.10$ & $\mathrm{n} / \mathrm{s}$ \\
\hline Relative weight (\%) & $0.29 \pm 0.02$ & $0.30 \pm 0.03$ & $0.34 \pm 0.03$ & $0.30 \pm 0.03$ & $\mathrm{n} / \mathrm{s}$ \\
\hline \multicolumn{6}{|l|}{ Prostate gland } \\
\hline Absolute weight (g) & $0.89 \pm 0.09$ & $1.01 \pm 0.08$ & $1.03 \pm 0.11$ & $1.06 \pm 0.09$ & $\mathrm{n} / \mathrm{s}$ \\
\hline Relative weight (\%) & $0.22 \pm 0.02$ & $0.25 \pm 0.02$ & $0.26 \pm 0.03$ & $0.27 \pm 0.02$ & $\mathrm{n} / \mathrm{s}$ \\
\hline
\end{tabular}

$\mathrm{n}=10$ for each group; Values are mean \pm SEM (for parametric data); $\mathrm{n} / \mathrm{s}$ Statistically not significant between all groups, $p>0.05 ;$ Relative organ weight $(\%)=($ Organ mass

/ body weight) $\times 100$

Gross examination at autopsy exposed no aberrant finding and the LR treatment did not affect the pregnancy and general condition of all female rats. Table 5 shows that foetal parameters did not significantly different in both treated and control groups. Our previous study showed that the hot water extract of $L$. rhinocerus contains the highest proportion of linoleic acid which is $21.35 \%$ followed by 2,3-dihydroxy propyl elaidate and octadecane with $11.82 \%$ and $10.47 \%$, respectively, through the GCMS analysis (Johnathan et al. 2016). Linoleic acid is the polyunsaturated fatty acid essential for arachidonic acid and cell membranes biosynthesis important for growth, reproduction and brain development (Berglund 2003). A new published study reported that fatty acids-high rich diet has positive roles and determines the performance of sperm motility and actions (Collodel et al. 2020). In addition, the maternal diet with the different amounts of linoleic acid composition influenced the placental and foetal weights and subsequently affected its growth and development in rats (Draycott et al. 2019). Thus, the presence of linoleic acid in the L. rhinocerus might indirectly play a crucial role to improve the fertility of rats.

Overall, the LR treatment administered did not cause any detrimental effect on the fertility of the rats of both sexes, while the litters did not show any substantial teratogenic effect. These findings are generally in agreement with the subacute and chronic toxicity experiments conducted on rats by Lee et al. (2013, 2011), respectively. Another reason this current study fails to find significant results is might be due to the small sample size. The sample size applied in this study is relatively adequate to assess the toxicity of a substance, but a larger sample size is recommended to gain statistical trustworthiness and help to strengthen the capability of the study to detect rare or low incidence effects (Hothorn 2014). 
TABLE 4. Absolute and relative weights of the female reproductive organs from the treated and control groups

\begin{tabular}{|c|c|c|c|c|c|c|c|c|c|}
\hline \multirow[t]{2}{*}{ Parameters } & \multirow{2}{*}{\multicolumn{2}{|c|}{$\begin{array}{c}\text { Group } 1 \\
\text { Control }(0 \mathrm{mg} / \mathrm{kg})\end{array}$}} & \multicolumn{2}{|c|}{ Group 2} & \multicolumn{2}{|c|}{ Group 3} & \multicolumn{2}{|c|}{ Group 4} & \multirow[t]{2}{*}{$p$-value } \\
\hline & & & $250 \mathrm{mg} / \mathrm{kg}$ & $0 \mathrm{mg} / \mathrm{kg}$ & $500 \mathrm{mg} / \mathrm{kg}$ & $0 \mathrm{mg} / \mathrm{kg}$ & $1000 \mathrm{mg} / \mathrm{kg}$ & $0 \mathrm{mg} / \mathrm{kg}$ & \\
\hline \multicolumn{10}{|l|}{ Right ovary } \\
\hline $\begin{array}{l}\text { Absolute } \\
\text { weight (mg) }\end{array}$ & $54.50 \pm 5.32$ & $75.60 \pm 7.98$ & $77.10 \pm 9.46$ & $65.0 \pm 2.34$ & $73.70 \pm 11.56$ & $55.40 \pm 5.48$ & $60.50 \pm 11.06$ & $69.90 \pm 4.47$ & $\mathrm{n} / \mathrm{s}$ \\
\hline $\begin{array}{l}\text { Relative } \\
\text { weight (\%) }\end{array}$ & $14.0 \pm 1.49$ & $18.70 \pm 1.66$ & $19.90 \pm 2.35$ & $16.30 \pm 0.89$ & $19.60 \pm 3.08$ & $13.10 \pm 1.17$ & $15.10 \pm 2.31$ & $16.70 \pm 0.92$ & $\mathrm{n} / \mathrm{s}$ \\
\hline \multicolumn{10}{|l|}{ Left ovary } \\
\hline $\begin{array}{l}\text { Absolute } \\
\text { weight (mg) }\end{array}$ & $56.90 \pm 2.78$ & $60.50 \pm 3.09$ & $63.40 \pm 13.94$ & $55.60 \pm 9.69$ & $62.50 \pm 5.83$ & $53.10 \pm 16.31$ & $54.20 \pm 5.45$ & $54.60 \pm 6.97$ & $\mathrm{n} / \mathrm{s}$ \\
\hline $\begin{array}{l}\text { Relative } \\
\text { weight (\%) }\end{array}$ & $14.70 \pm 0.87$ & $15.20 \pm 0.99$ & $16.50 \pm 3.65$ & $13.90 \pm 2.33$ & $16.60 \pm 1.54$ & $12.60 \pm 3.98$ & $13.60 \pm 1.36$ & $13.10 \pm 1.76$ & $\mathrm{n} / \mathrm{s}$ \\
\hline \multicolumn{10}{|l|}{$\begin{array}{l}\text { Right } \\
\text { fallopian } \\
\text { tube }\end{array}$} \\
\hline $\begin{array}{l}\text { Absolute } \\
\text { weight (mg) }\end{array}$ & $26.20 \pm 5.25$ & $24.80 \pm 2.82$ & $21.00 \pm 5.27$ & $19.50 \pm 4.48$ & $12.80 \pm 1.52$ & $14.70 \pm 4.28$ & $25.60 \pm 6.74$ & $21.20 \pm 2.11$ & $\mathrm{n} / \mathrm{s}$ \\
\hline $\begin{array}{l}\text { Relative } \\
\text { weight (\%) }\end{array}$ & $6.60 \pm 1.17$ & $6.10 \pm 0.60$ & $5.40 \pm 1.33$ & $4.90 \pm 1.13$ & $3.40 \pm 0.80$ & $3.50 \pm 1.03$ & $6.50 \pm 1.70$ & $5.10 \pm 0.54$ & $\mathrm{n} / \mathrm{s}$ \\
\hline \multicolumn{10}{|l|}{$\begin{array}{l}\text { Left fallopian } \\
\text { tube }\end{array}$} \\
\hline $\begin{array}{l}\text { Absolute } \\
\text { weight (mg) }\end{array}$ & $24.80 \pm 4.79$ & $19.40 \pm 2.95$ & $26.50 \pm 4.24$ & $17.70 \pm 1.67$ & $27.60 \pm 4.54$ & $18.80 \pm 3.03$ & $20.0 \pm 2.75$ & $20.40 \pm 1.96$ & $\mathrm{n} / \mathrm{s}$ \\
\hline $\begin{array}{l}\text { Relative } \\
\text { weight (\%) }\end{array}$ & $6.30 \pm 1.01$ & $4.90 \pm 0.86$ & $6.90 \pm 1.08$ & $4.40 \pm 0.35$ & $7.30 \pm 1.18$ & $4.50 \pm 0.71$ & $5.10 \pm 0.78$ & $4.90 \pm 0.50$ & $\mathrm{n} / \mathrm{s}$ \\
\hline \multicolumn{10}{|l|}{ Cervix } \\
\hline $\begin{array}{l}\text { Absolute } \\
\text { weight (mg) }\end{array}$ & $0.21 \pm 0.03$ & $0.20 \pm 0.04$ & $0.20 \pm 0.04$ & $0.20 \pm 0.01$ & $0.19 \pm 0.02$ & $0.19 \pm 0.02$ & $0.17 \pm 0.01$ & $0.17 \pm 0.02$ & $\mathrm{n} / \mathrm{s}$ \\
\hline $\begin{array}{l}\text { Relative } \\
\text { weight (\%) }\end{array}$ & $0.05 \pm 0.01$ & $0.05 \pm 0.01$ & $0.05 \pm 0.01$ & $0.05 \pm 0.004$ & $0.05 \pm 0.004$ & $0.04 \pm 0.004$ & $0.04 \pm 0.004$ & $0.04 \pm 0.004$ & $\mathrm{n} / \mathrm{s}$ \\
\hline
\end{tabular}

$\mathrm{n}=5$ for each dose group; Values are mean \pm SEM (for parametric data); $\mathrm{n} / \mathrm{s}$ Statistically not significant between all groups, $p>0.05 ;$ Relative organ weight $(\%)=($ Organ mass/corrected maternal body weight) $\times 100$

TABLE 5. Foetal parameters of LR-treated and control groups

\begin{tabular}{|c|c|c|c|c|c|c|c|c|c|}
\hline \multirow{3}{*}{$\begin{array}{l}\text { Parameters } \\
\text { No of corpora } \\
\text { lutea }\end{array}$} & \multirow{2}{*}{\multicolumn{2}{|c|}{$\begin{array}{c}\text { Group } 1 \\
\text { Control }(0 \mathrm{mg} / \mathrm{kg})\end{array}$}} & \multicolumn{2}{|c|}{ Group 2} & \multicolumn{2}{|c|}{ Group 3} & \multicolumn{2}{|c|}{ Group 4} & \multirow{3}{*}{$\frac{p \text {-value }}{} \frac{\mathrm{n} / \mathrm{s}}{}$} \\
\hline & & & \multirow{2}{*}{$\frac{250 \mathrm{mg} / \mathrm{kg}}{15.60 \pm 1.50}$} & \multirow{2}{*}{$\frac{0 \mathrm{mg} / \mathrm{kg}}{15.40 \pm 0.87}$} & \multirow{2}{*}{$\begin{array}{c}500 \mathrm{mg} / \mathrm{kg} \\
17.80 \pm 1.77\end{array}$} & \multirow{2}{*}{$\begin{array}{c}0 \mathrm{mg} / \mathrm{kg} \\
15.80 \pm 1.62\end{array}$} & \multirow{2}{*}{$\begin{array}{l}1000 \mathrm{mg} / \mathrm{kg} \\
14.00 \pm 1.98\end{array}$} & \multirow{2}{*}{$\begin{array}{c}0 \mathrm{mg} / \mathrm{kg} \\
14.8 \pm 2.08\end{array}$} & \\
\hline & $13.20 \pm 0.66$ & $15.20 \pm 1.59$ & & & & & & & \\
\hline $\begin{array}{l}\text { No of } \\
\text { implantation sites }\end{array}$ & $12.80 \pm 0.49$ & $11.20 \pm 1.86$ & $12.20 \pm 0.80$ & $12.20 \pm 0.58$ & $11.80 \pm 1.69$ & $12.20 \pm 0.66$ & $12.00 \pm 1.23$ & $12.2 \pm 1.20$ & $\mathrm{n} / \mathrm{s}$ \\
\hline $\begin{array}{l}\text { Post-implantation } \\
\text { loss/litter }(\%)^{\text {a }}\end{array}$ & $0(0.1)$ & 0 & 0 & $0(0.4)$ & $0(0.3)$ & 0 & 0 & 0 & $\mathrm{n} / \mathrm{s}$ \\
\hline \multicolumn{10}{|l|}{$\begin{array}{l}\text { Litters with } \\
\text { resorption }\end{array}$} \\
\hline Early resorption & 1 & 0 & 0 & 1 & 0 & 0 & 0 & 0 & - \\
\hline Late resorption & 0 & 0 & 0 & 1 & 1 & 0 & 0 & 0 & - \\
\hline $\begin{array}{l}\text { No of live } \\
\text { foetuses }\end{array}$ & $12.60 \pm 0.51$ & $11.20 \pm 1.86$ & $12.20 \pm 0.80$ & $11.40 \pm 0.81$ & $11.20 \pm 1.99$ & $12.20 \pm 0.66$ & $12.00 \pm 1.23$ & $12.2 \pm 1.20$ & $\mathrm{n} / \mathrm{s}$ \\
\hline $\begin{array}{l}\text { Foetal body } \\
\text { weight }(\mathrm{g})\end{array}$ & $5.07 \pm 0.40$ & $6.03 \pm 0.44$ & $5.81 \pm 0.53$ & $5.30 \pm 0.51$ & $5.03 \pm 0.20$ & $6.17 \pm 0.47$ & $6.42 \pm 0.23$ & $6.41 \pm 0.41$ & $\mathrm{n} / \mathrm{s}$ \\
\hline $\begin{array}{l}\text { Male: female sex } \\
\text { ratio }\end{array}$ & 1: 1.38 & $1: 1.29$ & 1: 1.18 & $1.23: 1$ & $1: 2.29$ & 1: 1.10 & 1: 1.07 & 1.64: 1 & $\mathrm{n} / \mathrm{s}$ \\
\hline
\end{tabular}

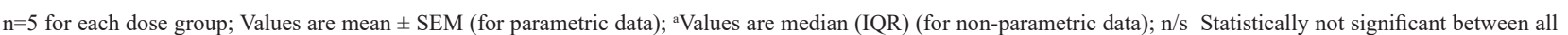
groups, $p>0.05$; Post-implantation loss $(\%)=($ No. implantation - No. live foetuses $/$ No. implantation $) \times 100$ 


\section{CONCLUSION}

Findings of the current study showed that no treatmentrelated toxicity in both sexes of all rats following LR treatment. Oral administrations of LR aqueous extract in different concentrations of $0,250,500$ and $1000 \mathrm{mg} /$ $\mathrm{kg}$ /day did not cause toxicity to all groups of animals as shown by normal general observation and behaviour, body weight, reproductive performance and reproductive hormones level. The fertility of male and female rats as well as the teratogenicity of offspring also exhibited no detrimental effect following LR treatment.

\section{ACKNOWLEDGEMENTS}

This research was supported by the Research University Grant 1001/PPSG/813065. The authors would like to express gratitude to the School of Health Sciences and Animal Research and Service Centre (ARASC), Health Campus, Universiti Sains Malaysia for all the facilities utilised throughout this study.

\section{REFERENCES}

Babu, S.R., Sadhnani, M.D., Swarna, M., Padmavathi, P. \& Reddy, P.P. 2004. Evaluation of FSH, LH and testosterone levels in different subgroups of infertile males. Indian Journal of Clinical Biochemistry 19(1): 45-49. doi: 10.1007/ bf02872388.

Baskaran, A. 2015. Suppression of lipopolysaccharide and hydrogen peroxide-induced inflammatory responses in raw 264.7 macrophage by Pleurotus giganteus and Lignosus rhinocerotis. University of Malaya. MS Thesis (Unpublished).

Berglund, L. 2003. Lipid biochemistry: An introduction. The American Journal of Clinical Nutrition 78(2): 353-354. doi: 10.1093/ajen/78.2.353a.

Collodel, G., Castellini, C., Lee, J.C.Y. \& Signorini, C. 2020. Relevance of fatty acids to sperm maturation and quality. Oxidative Medicine and Cellular Longevity 2020: 1-14. doi. org/10.1155/2020/7038124.

Coss, D., Jacobs, S.B., Bender, C.E. \& Mellon, P.L. 2003. Anovel AP-1 site is critical for maximal induction of the folliclestimulating hormone $\beta$ gene by gonadotropin-releasing hormone. Journal of Biological Chemistry 279(1): 152-162. doi: 10.1074/jbc.m304697200.

Draycott, S.A., Liu, G., Daniel, Z.C., Elmes, M.J., Muhlhausler, B.S. \& Langley-Evans, S.C. 2019. Maternal dietary ratio of linoleic acid to alpha-linolenic acid during pregnancy has sex-specific effects on placental and fetal weights in the rat. Nutrition \& Metabolism 16(1): 1-12. doi: 10.1186/s12986018-0330-7.

Hilaly, J.E., Israili, Z.H. \& Lyoussi, B. 2004. Acute and chronic toxicological studies of Ajuga iva in experimental animals. Journal of Ethnopharmacology 91(1): 43-50. doi: 10.1016/j. jep.2003.11.009.
Hilmi, W.M., Norliza, A. \& Sul'ain, D.M. 2013. Aphrodisiac properties of methanolic extract of Smilax myosotiflora tubers in male rats. International Journal of Medical Sciences and Biotechnology 1(2): 41-50.

Hothorn, L.A. 2014. Statistical evaluation of toxicological bioassays - A review. Toxicology Research 3(6): 418-432. doi: 10.1039/C4TX00047A.

Johnathan, M., Gan, S.H., Ezumi, M.W., Faezahtul, A.H. \& Nurul, A.A. 2016. Phytochemical profiles and inhibitory effects of tiger milk mushroom (Lignosus rhinocerus) extract on ovalbumin-induced airway inflammation in a rodent model of asthma. BMC Complementary and Alternative Medicine 16(1): 1-13. doi: 10.1186/s12906-016-1141-x.

Lau, B.F., Abdullah, N. \& Aminudin, N. 2013. Chemical composition of the tiger's milk mushroom, Lignosus rhinocerotis (Cooke) Ryvarden, from different developmental stages. Journal of Agricultural and Food Chemistry 61(20): 4890-4897. doi: 10.1021/jf4002507.

Lee, M.L., Tan, N.H., Fung, S.Y., Tan, C.S. \& Ng, S.T. 2012. The antiproliferative activity of sclerotia of Lignosus rhinoceros (tiger milk mushroom). Evidence-Based Complementary and Alternative Medicine 2012: 697603. doi: 10.1155/2012/697603.

Lee, S.S., Enchang, F.K., Tan, N.H., Fung, S.Y. \& Pailoor, J. 2013. Preclinical toxicological evaluations of the sclerotium of Lignosus rhinocerus (Cooke), the Tiger Milk mushroom. Journal of Ethnopharmacology 147(1): 157-163. doi: 10.1016/j.jep.2013.02.027.

Lee, S.S., Tan, N.H., Fung, S.Y., Pailoor, J. \& Sim, S.M. 2011. Evaluation of the sub-acute toxicity of the sclerotium of Lignosus rhinocerus (Cooke), the tiger milk mushroom. Journal of Ethnopharmacology 138(1): 192-200. doi: 10.1016/j.jep.2011.09.004.

Marques, P., Skorupskaite, K., George, J.T. \& Anderson, R.A. 2018. Physiology of GNRH and gonadotropin secretion. In Pituitary Disease and Neuroendocrinology, edited by Feingold, K.R., Anawalt, B., Boyce, A., Chrousos, G., de Herder, W.W., Dhatariya, K., Dungan, K., Grossman, A., Hershman, J.M., Hofland, J., Kalra, S., Kaltsas, G., Koch, C., Kopp, P., Korbonits, M., Kovacs, C.S., Kuohung, W., Laferrére, B., Levy, M., McGee, E.A., McLachlan, R., Morley, J.E., New, M., Purnell, J., Sahay, R., Singer, F., Sperling, M.A., Stratakis, C.A., Trence, D.L. \& Wilson, D.P. MDText.com, Inc.

Michael, B., Yano, B., Sellers, R.S., Perry, R., Morton, D., Roome, N., Johnson, J.K., Schafer, K. \& Pitsch, S. 2007. Evaluation of organ weights for rodent and non-rodent toxicity studies: A review of regulatory guidelines and a survey of current practices. Toxicologic Pathology 35(5): 742-750. doi: 10.1080/01926230701595292.

Mukinda, J.T. \& Eagles, P.F. 2010. Acute and sub-chronic oral toxicity profiles of the aqueous extract of Polygala fruticosa in female mice and rats. Journal of Ethnopharmacology 128(1): 236-240. doi: 10.1016/j.jep.2010.01.022. 
Nallathamby, N., Serm, L.G., Raman, J., Malek, S.N.A., Vidyadaran, S., Naidu, M., Kuppusamy, U.R. \& Sabaratnam, V. 2016. Identification and in vitro evaluation of lipids from sclerotia of Lignosus rhinocerotis for antioxidant and anti-neuroinflammatory activities. Natural Product Communications 11(10): 1485-1490. doi: 10.1177/1934578x1601101016.

Oduwole, O.O., Peltoketo, H. \& Huhtaniemi, I.T. 2018. Role of follicle-stimulating hormone in spermatogenesis. Frontiers in Endocrinology (Lausanne). 9: 763. doi: 10.3389/ fendo.2018.00763/full.

OECD. 2016. Test No. 422: Combined repeated dose toxicity study with the reproduction/developmental toxicity screening test, OECD Guidelines for the Testing of Chemicals, Section 4, OECD Publishing, Paris. Organisation for Economic Co-operation and Development (OECD). doi: 10.1787/9789264264403-en.

Piao, Y., Liu, Y. \& Xie, X. 2013. Change trends of organ weight background data in Sprague Dawley rats at different ages. Journal of Toxicologic Pathology 26(1): 29-34. doi: 10.1293/ tox.26.29.

Sellers, R.S., Mortan, D., Michael, B., Roome, N., Johnson, J., Yano, B.L., Perry, R. \& Schafer, K. 2007. Society of toxicologic pathology position paper: Organ weight recommendations for toxicology studies. Toxicologic Pathology 35(5): 751-755. doi: 10.1080/01926230701595300.
Suziana Zaila, C.F., Farida Zuraina, M.Y., Norfazlina, M.N., Lek Mun, L., Nurshahirah, N., Florinsiah, L. \& Rajab, N.F. 2013. Antiproliferative effect of Lignosus rhinocerotis, the tiger milk mushroom on HCT 116 human colorectal cancer cells. In The Open Conference Proceedings Journal. TOCPR. 4(1): 65-70. doi: 10.2174/2210289201304020065.

Teo, S., Stirling, D., Thomas, S., Hoberman, A., Kiorpes, A. \& Khetani, V. 2002. A 90-day oral gavage toxicity study of d-methylphenidate and d,l-methylphenidate in SpragueDawley rats. Toxicology 179(3): 183-196. doi: 10.1016/ s0300-483x(02)00338-4.

Thackray, V.G. 2014. Fox tales: Regulation of gonadotropin gene expression by forkhead transcription factors. Molecular and Cellular Endocrinology 385(1-2): 62-70. doi: 10.1016/j. mce.2013.09.034.

Young, S.L. 2013. Oestrogen and progesterone action on endometrium: A translational approach to understanding endometrial receptivity. Reproductive BioMedicine Online 27(5): 497-505. doi: 10.1016/j.rbmo.2013.06.010.

Programme of Biomedicine

School of Health Sciences

Universiti Sains Malaysia Health Campus

16150 Kubang Kerian, Kelantan Darul Naim

Malaysia

*Corresponding author; email: wanezumi@usm.my

Received: 12 March 2020

Accepted: 19 January 2021 